\title{
Charles B. Duke Receives 1997 Woody Award
}

Charles B. Duke, vice president and senior research Fellow in the Xerox Corporate Research and Technology Group, is the recipient of the 1997 Materials Research Society Woody Award. He has served the Society "faithfully and unflaggingly," according to 1997 MRS president Robert Hull. The honor was bestowed on Duke at the 1997 MRS Fall Meeting in Boston.

"Duke has always been the source of frank, honest, and sound counsel," said Hull. "As president last year, I benefitted immensely from his knowledge."

Duke received the award "in recognition of outstanding service and dedication, on behalf of MRS, as exemplified by Woody White. " This service began with Journal of Materials Research, for which Duke was the founding editor-in-chief. Prior to his work with $J M R$, Duke had served on publication boards at the American Institute of Physics and the American Vacuum Society.

"Duke aggressively acquired manuscripts for $J M R, "$ said Elton Kaufmann, MRS president in 1985 when the journal originated. In addition to his initial role overseeing the publication, Duke served on the Advisory Review Board in 1993.

Another significant achievement of Duke's was his work to change the finan-

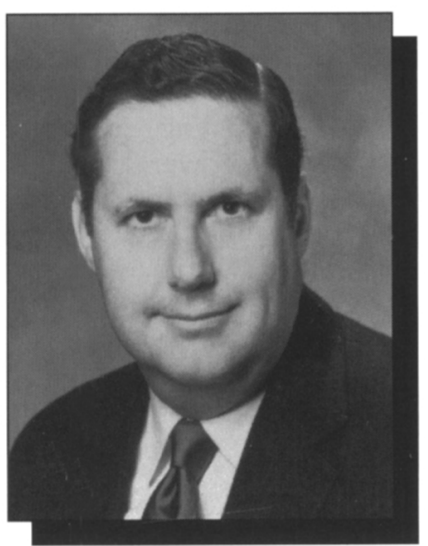

cial outlook of the Society during his tenure as treasurer in 1991 and 1992. "Duke's contributions came at a critical time when the Society had grown to a level at which professional budget controls were needed. His wisdom and diligence helped us adopt the perspective necessary to transform MRS from a small, struggling society to the stable, wellrespected organization it is today," said Jim Roberto, 1991 MRS president.

The development of $I M R$ and his time as treasurer are what Duke sees as his two greatest MRS accomplishments. In regard to the latter, he said, "I helped put the Society on sound financial footing through a complete overhaul of the budgeting process. The rest is history."

Duke's other offices include Council terms in 1988 and 1995 . He served as chair of the Publications Committee in 1988 and as chair of the Audit Committee in 1997. Also in 1997 he was a member of the MRS Headquarters New Building Task Force. "Duke showed us how to set our goals for the project around 'customer' needs," said 1997 councillor Alan Taub who chaired the task force. "In addition he provided insight into building requirements, gained during his experience with similar projects at Xerox."

Duke received a $\mathrm{PhD}$ degree in physics from Princeton University following a BS degree summa cum laude with distinction in mathematics from Duke University. His research interests include surface science, semiconductor physics, the electronic structure of molecular solids, and electron tunneling in solids. He is currently the editor of and was the guest editor of a special commemorative volume, Surface Science: The First Thirty Years, published in 1994 as volumes 299/300 of Surface Science.

\section{MRS Invites Nominations for the Von Hippel Award, Turnbull Lectureship, and MRS Medal}

The Materials Research Society is seeking nominations for the Von Hippel Award, the Turnbull Lectureship, and the MRS Medal. The deadline for nominations is June 1, 1998. These awards will be presented at the 1998 MRS Fall Meeting, November 30-December 4, in Boston.

The MRS Awards Program recognizes outstanding contributors to the progress of materials research. Nomination forms and details about eligibility and nomination criteria are available from Amy Wilson, Materials Research Society, 506 Keystone Drive, Warrendale, PA 15086-7573; phone 724-779-3004 ext. 523; fax 724-779-8313. Further information about each award can also be obtained from the MRS website at http:/ / www.mrs.org/awards/index.html.

\section{Von Hippel Award Acknowledges Outstanding Interdisciplinary Work in Materials Research}

The Von Hippel Award, first presented to Arthur R. Von Hippel whose interdisciplinary and pioneering research typified the spirit of the award, is the Materials Research Society's highest honor. The recipient is recognized for brilliance and originality combined with vision that transcends the boundaries of conventional scientific disciplines. The Award includes a $\$ 10,000$ cash prize, honorary membership in MRS, and a unique trophy-a mounted ruby laser crystal symbolizing the manyfaceted nature of materials research.

Selection of the recipient is determined by a vote of the MRS Council. The recipient will be invited to speak at the Awards Ceremony.

\section{Turnbull Lectureship Honors Career of an Outstanding Researcher and Communicator}

The David Turnbull Lectureship recognizes the career of a scientist who has made outstanding contributions to understanding materials phenomena and properties through research, writing, and lecturing, as exemplified by the life work of David Turnbull. While honoring the accomplishments of the recipient, the
Turnbull Lectureship is intended to support and enrich the materials research community.

The recipient will give a technical lecture of broad appeal at a designated session of the 1998 MRS Fall Meeting. The Turnbull Lecturer will receive a $\$ 5,000$ honorarium and a citation plaque, along with travel expenses paid to enable the recipient to address MRS Sections and University Chapters, and/or participate in the production of a video version of the lecture.

\section{MRS Medal Recognizes Recent Discovery or Advancement in Materials Science}

The MRS Medal offers public and professional recognition of an exceptional recent achievement in materials research. A medal will be awarded for a specific outstanding recent discovery or advancement which is expected to have a major impact on the progress of any materials-related field.

The award consists of a $\$ 3,000$ cash prize, an engraved and mounted medal, and a citation certificate. 


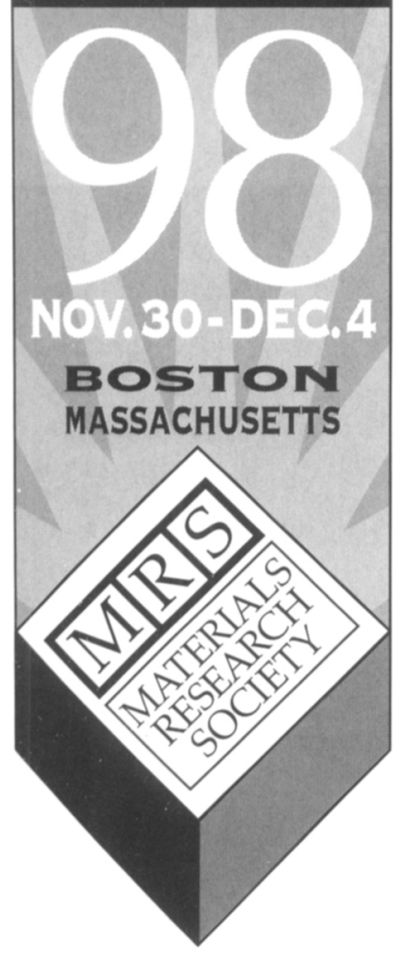

June 8,1998 for abstracts submitted by mail or fax

June 22, 1998 for abstracts submitted by the MRS Web site or e-mail

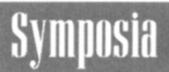

A: Polycrystalline Thin Films-

Processing-Structure-Property Relationships

B: Growth Instabilities and Decomposition During Heteroepitaxy

C: Surface and Interface Structure and Dynamics

D: Integration of Dissimilar Materials in Microand Optoelectronics

E: Film Growth and Processing Using Hyperthermal Beams

F: Microcrystalline and Nanocrystalline Semiconductors

G: GaN and Related Alloys

$\mathrm{H}$ : Infrared Semiconductor Materials and Devices

I: III-V and SiGe Group IV Device/IC Processing Challenges for Commercial Applications

$\mathrm{J}$ : Multiscale Modeling of Materials

K: Computation of Rates of Activated Processes

$\mathrm{L}$ : Interaction of Phase and Defect Microstructures in Metallic Alloys

M: Fracture and Ductile vs Brittle Behavior-Theory, Modeling, and Experiment

$\mathrm{N}$ : Microstructural Processes in Irradiated Materials

O: Ferroelectric Thin Films VII

P: Magnetic Oxides and Oxide Devices

Q: High-Temperature SuperconductorsMaterials Challenges

R: Organic Electronic and Photonic Materials and Devices

S: Carbon Nanotubes, Fullerenes and Related Carbon Materials

T: Recent Progress in Optical Data Storage and Processing

U: Organics with Supramolecular Structure and Function
V: Solid Freeform and Additive Fabrication

W: Dynamics in Small Confining Systems V

$\mathrm{X}$ : Frontiers of Materials Research

Y: Plasma Deposition and Treatment of Polymers

Z: Thermoelectric Materials-The Next Generation Materials for Small-Scale Refrigeration and Power Generation Applications

AA: Materials Science of Microelectromechanical System (MEMS) Devices

BB: Nonlithographic Methods for Organizing Materials into Functional Structures

CC: Combinatorial Chemistry and Materials Science

DD: Solid-State Chemistry of Inorganic Materials II

EE: Solid-State lonics

FF: Advanced Catalytic Materials 1998

GG: Polymeric Materials-Drugs, Delivery and Devices

$\mathrm{HH}$ : Tissue Engineering

II: Advanced Materials, Coatings, and Biological Cues for Medical Implants

$\mathrm{JJ}$ : Materials in Space-Science, Technology, and Exploration

KK: High-Temperature-Ordered Intermetallic Alloys VIII

LL: Quasicrystals

MM: Bulk Metallic Glasses

NN: Aging of Engineered Systems with Focus on Aircraft

OO: Properties and Processing of Vapor-Deposited Coatings

PP: Recent Advances in Ceramic Matrix CompositesStructural Design, Fabrication, and Long-Term Use

$\mathrm{QQ}$ : Scientific Basis for Nuclear Waste Management XXII

RR: Workshop on Materials Education

\section{Fall Meetinn Cheirs}

\section{Clyde L. Briant}

Division of Engineering, Box D

Brown University

182 Hope Street

Providence, RI 02912-9104

Phone 401-863-2626

Fax 401-863-7677

clyde_briant@brown.edu
Eric H. Chason

MS 1415

Sandia National Laboratories

P.O. Box 5800

Albuquerque, NM 87185-1415

Phone 505-844-8951

Fax 505-844-1197

ehchaso@sandia.gov
Howard E. Katz

Lucent Technologies

Bell Laboratories

600 Mountain Avenue, 1D-249

Murray Hill, NJ 07974

Phone 908-582-6968

Fax 908-582-3609

hek@bell-labs.com
Yuh Shiohara
SRL Division 4
ISTEC
1-10-13 Shinonome Koto-ku
Tokyo 135, Japan
Phone 81-3-35365710
Fax 81-3-35365717
shiohara@istec.or.jp

For general 1998 Fall meeting information, a Call for Papers, Program Book, or information on symposium tutorials, publications, exhibit, job center, or symposium assistant positions contact:

\section{MRS Member Services}

Materials Research Society

506 Keystone Drive, Warrendale, PA 15086-7573

Phone: 724-779-3003 • Fax: 724-779-8313

E-mail: info@mrs.org • http://www.mrs.org/ 